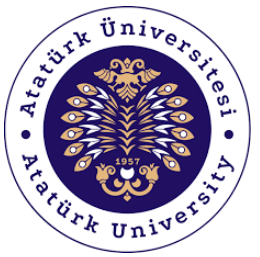

Doğu Coğrafya Dergisi

Haziran-2021, Y11: 26, Say1: 45, Sayfa: 183-194

Eastern Geographical Rewiew

June-2021 Volume: 26, Numbers: 45, Page: 183-194

DOİ: https://doi.org/ 10.17295/ataunidcd.933070

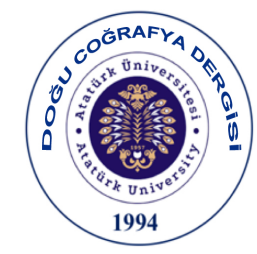

Atıf/Citiation

Öztürk, S., Işınkaralar, Ö., Yılmaz, D., (2021), Restorasyon çalışmaları sonrası yerel halkın algı ve tutumları (Kayseri kalesi örneği). Doğu Coğrafya Dergisi 26(45), 183-194

\title{
RESTORASYON ÇALIŞMALARI SONRASI YEREL HALKIN ALGI VE TUTUMLARI (KAYSERİ KALESİ ÖRNEĞİ)
}

Perception and Attitude of Local People After Restoration (Example of Kayseri)

\author{
Doç. Dr. Sevgi ÖZTÜRK* \\ Arş.Gör. Öznur IŞINKARALAR ${ }^{* *}$ \\ Dilara YILMAZ ${ }^{* * *}$
}

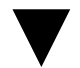

$\ddot{O} z$

Tarihi çevreler, bulunduklarl kentlerin geçmiş dönemlerinin ekonomik, sosyal ve kültürel özelliklerini, yaşam tarzların yansıtan kültürel miras alanlarıdır. Kültürel miraslar kültür turizmi için önemli bir kaynak değeridir. Bir turizm kaynağının planlı ve sürdürülebilir gelişimi için yapılan koruma süreçlerinden yerel halkin bu sürece yönelik tutumunun belirlenmesi son derece önemlidir. Çalışma, Türkiye'nin tarihi açıdan önemli olan Kayseri ilinde yürütülmüs Olup tarihi ve kültürel çevrenin korunmasinda sivil toplumun rolü ve memnuniyet durumları araştırılmıştır. Araştırma kapsamında Kayseri Kalesi'ne yapılan restorasyon uygulamaları ele alınmış, anket tekniği kullanılarak uygulama hakkındaki genel yerel halkın görüşleri tespit edilerek, restorasyon çallşmasindan memnuniyet durumları değerlendirilmiştir. Yerel halkın demografik özellikleri ve memnuniyet düzeyleri arasindaki ilişskiyi belirlemek amacıyla ki-kare bağımsızlık testi yapılmıștır. Genel olarak yerel halkın koruma sürecinden ve restorasyon çalışmalarından memnuniyet seviyesinin düşük olması ulaşılan önemli bir sonuç olmuştur.

Anahtar Kelimeler: Tarihi ve kültürel çevre, koruma süreci, yerel halkın memnuniyeti, restorasyon çalışmaları.

\section{Abstract}

Historical environments are cultural heritage areas that reflect the economic, social, and cultural characteristics and lifestyles of the past periods of the cities in which they are located. Cultural heritage is an important resource value for cultural tourism. It is extremely important to determine the attitude of the local people towards this process, which is one of the conservation processes for the planned and sustainable development of a tourism resource. The study was carried out in the historically important city of Kayseri, Turkey, and the role of civil society in the protection of the historical and

* Kastamonu Üniversitesi, Mühendislik ve Mimarlık Fakültesi, Peyzaj Mimarlı̆̆ 1 Bölümü, sozturk@kastamonu.edu.tr, ORCID: 0000-0002-3383-7822

** Kastamonu Üniversitesi, Mühendislik ve Mimarlık Fakültesi, Peyzaj Mimarlığı Bölümü, obulan@kastamonu.edu.tr, ORCID: 0000-0001-9774-5137

*** Sorumlu yazar, Doktora Öğrencisi, Kastamonu Üniversitesi, Fen Bilimleri Enstitüsü, Peyzaj Mimarlığı Ana Bilim Dal1, dlara.ylmaz94@,gmail.com, ORCID: 0000-0002-9151-0529

Dergiye Geliş Tarihi: 05.05.2021

Yayına Kabul Tarihi: 20.06.2021 
cultural environment and their satisfaction were investigated. Within the scope of the research, the restoration applications made to Kayseri Castle were discussed, the opinions of the general local people about the application were determined using the survey technique, and their satisfaction with the restoration work was evaluated. A Chi-square independence test was conducted to determine the relationship between demographic characteristics and satisfaction levels of local people. In general, the low level of satisfaction of the local people with the conservation process and restoration work has been an important result.

Keywords: Historical and cultural environment, conservation process, a satisfaction of local people, restoration works. 


\section{Giriş}

Yaşayan önemli bir varlık olarak değerlendirilen kentler, sürekli yenilenme ve değişim süreci içerisindedir. Toplumlarda meydana gelen ekonomik ve sosyal değişimlere bağlı olarak kentlerde yeni ihtiyaçlar ortaya çıkmaktadır. Bu ihtiyaçlar ise kentlere yeni işlevler yüklenmesini ve bu duruma bağlı olarak eski tarihi yapıların yeniden kullanımlarının veya yeni yapıların inşa edilmesini gerekli kılmaktadır. Yapılan yanlış uygulamaların sonuçları, kentlerin mimarisinde ve özellikle kentlerin tarihi dokusunda geri dönüşü olmayan bozulmalara neden olmaktadır (Arabacı ve Aydemir, 2007; Önaç vd., 2018; Öztürk vd., 2018).

Fiziki bir mekân kurgusu ile kendilerine özgü değerleri yansıtan tarihi ve kültürel çevreler, tarihte yaşamış olan çeşitli uygarlıkların yaşam birikimleri ile oluşmuştur. Bu yüzden tarihi kent mekânları, doğal yaşam koşullarının ve geleneklerin hızla değiştiği dünyada geçmiş dönemlerde yaşanan çevreyi gösteren açık hava müzeleri olarak görülmektedir (Ahunbay, 2004; Nijkamp ve Riganti, 2009; Perucca, 2018). Kentlerin bu önemli alanlarının günümüz yaşam koşulları ile bütünleştirilerek yaşatılması ve gelecek kuşaklara aktarılması kent kimliğinin devamlılığını sağlamak adına oldukça önemlidir (Tırnakçı ve Aklıbaşında, 2018; Öztürk vd., 2021).

Tarihi ve kültürel çevreler, geleneksel kent dokuları, geçmişte yaşanmış birçok olayın kanıtları olarak mekânsal ve kültürel anlamda önemli farklılıklara sahiptir. Tarihi çevrelerin yaşatılması amacı ile ortaya çıkan koruma kavramı, ilk zamanlarda sadece önemli yapıları korumak anlamında kullanılmıştır. Günümüzde ise değişimin ortaya konması, yaşatılması, tarihi geçmişe dayalı olarak kimliğin devam ettirilmesi ve en önemlisi yapıların kent ve doğal çevre ile birlikte yaşatılması kapsamında kullanılmaktadır (Dönmez ve Türkmen, 2015).

Geçmişte korunan alanlarda, insana karşı bir planlama anlayışı benimsenmiştir. Fakat bu anlayışla yapılan uygulamalar sonucunda yerel toplumun benimsemediği bir koruma modelinin başarısız olduğu görülmüsşür. Son yıllarda ise benimsenen yeni anlayışta yerel halkın da dâhil edildiği koruma modelleri esas alınmaktadır (Phillips, 2002; Aslan ve Uzun, 2020). Koruma çalışmalarında yapılan yanlış uygulamalar sonucunda tarihi alanların zarar görmesi önemli alan sorunlarından birisidir. Bu sorunlardan en çok etkilenen kesim ise o bölgede yaşayan insanlardır. Bu açıdan yerel halkın koruma çalışmalarına bakış açısı önemlidir (Avcıkurt, 2003; Mansuroğlu, 2006; Çam ve Çılgınoğlu, 2020).

Araştırma kapsamında Kayseri'nin tarihi geçmişini yansıtan Kayseri Kalesi'ne yapılan restorasyon çalışması ele alınmıştır. Çalışmada, Kalenin bulunduğu çevrede alan araştırması yapılarak kentsel ve tarihi bir çevrede yaşayanların koruma sürecinden memnuniyeti sorgulanmıştır.

\section{Materyal ve Yöntem}

Araştırma materyalini oluşturan Kayseri, İç Anadolu Bölgesi'nde bulunmakta olup Orta Kızılırmak Bölümü'nde Erciyes Dağı'nın eteklerinde kurulmuş bir ildir. Kuzeyde Yozgat, güneyde Adana, doğuda Kahramanmaraş ve batıda Nevşehir illeriyle komşudur (Şubaşı,1998) (Şekil 1). $16.969 \mathrm{~km}^{2}$ yüz ölçümüne sahip olan ilde $\mathrm{km}^{2}$ 'ye 84 kişi düşsmektedir. İlin merkez ilçeleri 582.055 nüfus ile Melikgazi ve 400.726 nüfus ile Kocasinan'dır (TUIK, 2020).

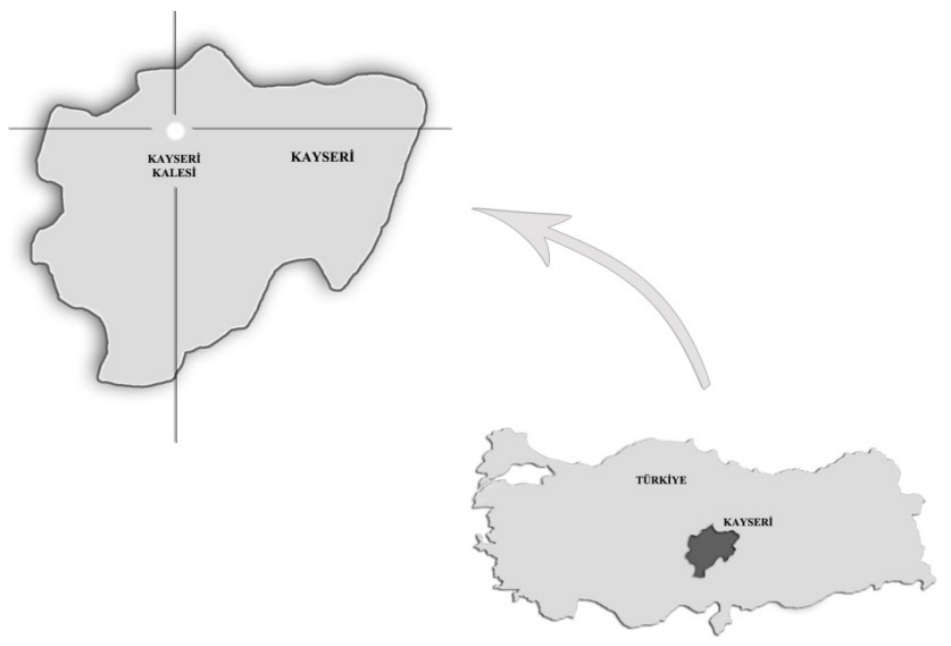

Şekil 1. Çalışma alanının konum haritası 
Dünyanın en eski şehirlerinden birisi olan Kayseri klasik çağlarda güzel atlar ülkesi anlamına gelen “Kapadokya” adı verilen bölgedir. Kızılırmak’ın güneyinde bulunan bu alan, Tuz Gölü’nden Fırat nehrine kadar uzanmaktadır. Tarihte İpek Yolu üzerinden geçen bu bölge pek çok medeniyete de ev sahipliği yapmıştır. Kent, tarihi ticaret yolları üzerinde bulunmasından dolayı Selçuklular döneminde ticari ve kültürel merkez durumuna gelmiştir. Çalışmaya da konu olan Kayseri Kalesi'nin surları bu dönemde onarılmıştır. Kaleiçi'nde devlet daireleri, camiler, saraylar yapılırken; kale dışına ise Pazar yerleri, hanlar inşa edilmiştir. Tarihin her döneminde önemini korumuş olan Kayseri'nin en önemli tarihi miras alanlarından birisi olan Kayseri Kalesi, şehir içerisinde geniş bir alana sahiptir (Çayırdă̆, 2001).

Kayseri Kalesi Restorasyon uygulamaları hakkında yerel halkın koruma sürecinden memnuniyetinin araştırıldığı çalışmada anket tekniği kullanılarak birincil kaynaklardan veriler toplanmıştır. Kayseri Kalesi hakkında genel değerlendirmelerin ve restorasyon uygulamaları hakkında memnuniyetin sorgulandı̆̆ 1 anket 3 bölümden oluşmaktadır. İlk bölüm, tarihi ve kültürel çevrede yaşayanlar ile ilgili demografik bilgilerden oluşmaktadır. İkinci bölümde katılımcılardan Kayseri Kalesi hakkında genel görüşlerini belirlemek amacıyla 6 adet soru yöneltilmiş ve cevaplamaları istenmiştir. Üçüncü bölümde ise tarihi çevrede yaşayan katılımcıların Kayseri Kalesi restorasyon uygulamalarından memnun kalıp kalmadıklarını tespit etmeye yönelik olarak 3'lü likert ölçeğinde (1:katılmıyorum, 2:kararsızım, 3:katılıyorum) 8 adet soru bulunmaktadır.

Anket, tarihi ve kültürel çevrede yaşayan, araştırmaya gönüllülük esası ile katılım gösteren yerel halktan 450 kişiyle yapılmıştır. Elde edilen veriler SPSS programında analiz edilmiştir. İlk olarak verilerin güvenilirlik durumu Cronbach Alpha değeri hesaplanarak test edilmiştir. Cronbach's Alpha katsayısı ile güvenilirlik değerlendirmesi belirli ölçütlere göre yapılmaktadır (Özdamar, 1997; Öztürk vd., 2019). Bu ölçütlere göre veriler “oldukça güvenilir” olarak çalışmada kullanılmıştır (Tablo 1). Daha sonra elde edilen veriler ki-kare testi ile analiz edilmiştir.

Tablo 1. Güvenilirlik analizi

\begin{tabular}{|c|c|c|c|}
\hline & Kriterler & Cronbach's Alpha & $\mathrm{N}$ of Items \\
\hline \multirow{15}{*}{ 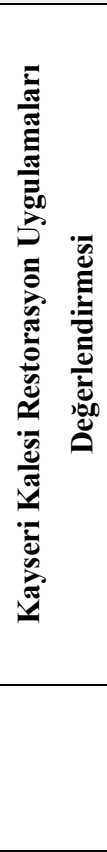 } & Restorasyon uygulamaları tarihi geçmişi yok etmiştir. & \multirow{15}{*}{,810 } & \multirow{11}{*}{8} \\
\hline & Restorasyon uygulamaları sonrasında yapılan koruma & & \\
\hline & çalışmaları yeterlidir. & & \\
\hline & Restorasyon uygulamaları kentin oluştuğu dönemi & & \\
\hline & yansitmaktadır. & & \\
\hline & Restorasyon sonrası kale içerisindeki rekreasyonel ve sosyal & & \\
\hline & kullanım alanları yeterlidir. & & \\
\hline & $\begin{array}{l}\text { Restorasyon uygulamaları çevredeki kullanım alanları ile } \\
\text { bağlantılıdır. }\end{array}$ & & \\
\hline & Restorasyon sonrası kullanım alanları yeterlidir. & & \\
\hline & $\begin{array}{l}\text { Restorasyon uygulamaları sonrasındaki güvenlik çalışmaları } \\
\text { yeterlidir. }\end{array}$ & & \\
\hline & $\begin{array}{l}\text { Restorasyon uygulamalarını yerli ve yabancı turistler } \\
\text { bilmektedir. }\end{array}$ & & \\
\hline & $0.00<0.40$ ise güvenilir değildir & & \\
\hline & $0.40<0.60$ ise düşük güvenilirliktedir & & \\
\hline & $0.60<0.80$ ise oldukça güvenilirdir ve & & \\
\hline & $0.80<1.00$ ise yüksek derecede güvenilir & & \\
\hline
\end{tabular}

\section{Bulgular}

Anket uygulamasına katılan yerel halkın demografik bilgileri Tablo 2'de verilmiștir. Bu bilgilere göre, katılımcıların \%59'u kadın, \%41'i erkektir. Katılımcıların \%46’sı 26-35, \%44'ü 18-25 yaş aralığındadır. Eğitim durumları değerlendirildiğinde \%49'u üniversite, \%46'sı lise eğitim düzeyinde iken katılımcılar yoğunluklu olarak kamu sektöründe $(\% 51)$ çalıştıklarını belirtmişlerdir. 
Tablo 2. Katılımciların demografik bilgileri

\begin{tabular}{|c|c|c|c|}
\hline Nitelikler & Nitelik Grupları & $\mathbf{n}$ & $\%$ \\
\hline \multirow{2}{*}{ Cinsiyet } & Kadın & 265 & 59 \\
\hline & Erkek & 185 & 41 \\
\hline \multirow{5}{*}{ Yaş } & $18-25$ & 198 & 44 \\
\hline & $26-35$ & 209 & 46 \\
\hline & $36-45$ & 22 & 5 \\
\hline & $46-55$ & 19 & 4 \\
\hline & $56+$ & 2 & 1 \\
\hline \multirow{5}{*}{ Eğitim } & İlkokul & 12 & 3 \\
\hline & Ortaokul & 2 & 1 \\
\hline & Lise & 211 & 46 \\
\hline & Üniversite & 223 & 49 \\
\hline & Lisansüstü & 2 & 1 \\
\hline \multirow{6}{*}{ Meslek } & Kamu sektörü & 228 & 51 \\
\hline & Özel sektör & 114 & 25 \\
\hline & Öğrenci & 66 & 15 \\
\hline & Ev hanımı & 15 & 3 \\
\hline & Emekli & 16 & 4 \\
\hline & Serbest meslek & 11 & 2 \\
\hline
\end{tabular}

Anketin ikinci bölümünde ilk olarak katılımcıların Kayseri Kalesi’ne restorasyon öncesinde gelip gelmedikleri sorgulanmıştır. Katılımcıların \%58'i daha önceden geldiğini belirtirken aynı zamanda tarihi ve kültürel açıdan önemli olan Kale'nin restorasyon çalışmasına ihtiyacının olduğunu belirtmişlerdir.

Yerel halkın Kayseri Kalesi hakkında genel görüş ve değerlendirmelerini öğrenmek amacıyla katılımcılara ilk olarak "Kale’nin en önemli niteliği” "sorulmuştur. Katılımcıların \%50'si tarihi-kültürel bir değer olduğunu belirtmişlerdir. İkinci olarak katılımcılara "Kale 'yi hangi durumlarda ziyaret ettikleri”" sorulmuştur. Katılımcıların \%45'i arada isteğe bağlı, \%35'i ise gün içerisinde geçiş noktası olması dolayısıyla ziyaret ettiklerini belirtmişlerdir. Üçüncü olarak katılımcılara "Kale'yi ziyaret ederken tercih ettikleri zaman aralığl " sorulmuştur. Katılımcıların \%47'si öğleden sonraki zaman aralığında ziyaret ettiklerini belirtmişlerdir. Dördüncü soruda katılımcıların "Kale'ye hangi sıklıkla geldikleri” sorgulanmıştır. Katılımcıların \%53'ünün nadiren geldikleri tespit edilmiştir. Daha sonra katılımcılara “Kale’ye gelirken kullandıkları ulaşım türü” sorulmuştur. Katılımcıların \%49'u toplu taşıma ile geldiklerini belirtmişlerdir. Son olarak ise katılımcılara "Kale’ye geldiklerinde ne kadar süre vakit geçirdikleri” sorulmuştur. Katılımcıların \%74'ü 2-3 saat vakit geçirdiklerini belirtmişlerdir (Tablo 3).

Tablo 3. Katılımcıların Kayseri Kalesi hakkında genel görüş ve değerlendirmeleri

\begin{tabular}{|c|c|c|c|}
\hline Sorular & Cevaplar & n & $\%$ \\
\hline \multirow{3}{*}{ Kale'nin en önemli niteliği } & Tarihi-kültürel & 226 & 50 \\
\hline & Medeniyet & 169 & 38 \\
\hline & Turizm & 55 & 12 \\
\hline \multirow{3}{*}{$\begin{array}{l}\text { Kale'nin hangi durumlarda } \\
\text { ziyaret edildiği }\end{array}$} & Arada isteğe bağlı olarak & 203 & 45 \\
\hline & Geçiş noktası olarak & 157 & 35 \\
\hline & Planlı olarak & 90 & 20 \\
\hline \multirow{4}{*}{$\begin{array}{l}\text { Kale'yi ziyaret ederken tercih } \\
\text { edilen zaman aralığ } 1\end{array}$} & Sabah & 43 & 10 \\
\hline & Öğlen & 96 & 21 \\
\hline & Öğleden sonra & 213 & 47 \\
\hline & Akşam & 98 & 22 \\
\hline \multirow{4}{*}{ Kale’ye ne sıklıkla gelindiği } & Her gün & 16 & 4 \\
\hline & Haftada 1-3 kez & 85 & 19 \\
\hline & Ayda 1-3 kez & 110 & 24 \\
\hline & Nadiren & 239 & 53 \\
\hline \multirow{3}{*}{$\begin{array}{l}\text { Kale'ye gelirken kullanılan } \\
\text { ulaşım türü }\end{array}$} & Toplu taşıma & 219 & 49 \\
\hline & Yaya & 150 & 33 \\
\hline & Özel araç & 81 & 18 \\
\hline \multirow{3}{*}{ Kale'de geçirilen süre } & 1 saatten az & 110 & 24 \\
\hline & $1-3$ saat & 332 & 74 \\
\hline & 4 saat ve daha fazla & 8 & 2 \\
\hline
\end{tabular}

Çalışmada yerel kalkın Kayseri Kalesi koruma sürecinden memnuniyet düzeylerini belirlemek amacıyla anket tekniğinden elde edilen veriler SPSS programında ki-kare testi ile değerlendirilmiştir. Testte katılımcıların 
cinsiyetleri, yaşları, eğitim düzeyleri ve meslekleri ile restorasyon uygulamaları sonucundan memnuniyetlerini tespit etmek amacıyla sorgulanan kriterler arasında istatistiksel olarak anlamlı bir ilişki olup olmadığ sorgulanmıştır.

Ki-kare sonuçlarına göre yerel halkın cinsiyeti ile restorasyon çalışmasından memnuniyet düzeyleri karşılaştırıldığında; katılımcıların cinsiyetleri ile memnuniyet durumları arasında anlamlı bir ilişki olduğu görülmektedir $(\mathrm{p}<0,005)$. Genel olarak bakıldı̆̆ında katılımcıların restorasyon çalışmalarından memnuniyet düzeylerinin düşük olduğu tespit edilmiştir. Fakat kadın katılımcıların erkeklere oranla memnuniyet düzeyleri daha düşüktür. Özellikle koruma çalışmalarının Kayseri'nin tarihini yok ettiğinin (K1), koruma çalışmalarının yeterli olmadığının (K2) düşünülmesi kadın katılımcılar tarafından daha fazla belirtilmiştir. Restorasyon çalışmaları sonrasında yapılan kullanım alanlarının yetersiz olması kriteri de (K6) kadınlar tarafından daha fazla belirtilen bir diğer nitelik olmuştur (Tablo 4).

Tablo 4. Katılımcıların cinsiyetleri ile memnuniyet düzeylerinin karşılaştırılması

\begin{tabular}{|c|c|c|c|c|c|c|c|}
\hline \multicolumn{2}{|r|}{ Kriterler } & \multirow{2}{*}{$\begin{array}{l}\text { Cinsiyet } \\
\text { Kadın }\end{array}$} & \multirow{2}{*}{$\begin{array}{c}1 \\
77\end{array}$} & \multirow{2}{*}{$\begin{array}{c}2 \\
72\end{array}$} & \multirow{2}{*}{$\begin{array}{c}3 \\
116\end{array}$} & \multirow{3}{*}{$\begin{array}{c}\begin{array}{c}\text { Chi- } \\
\text { Square }\end{array} \\
13,736 \text { (a) }\end{array}$} & \multirow{3}{*}{$\begin{array}{c}\begin{array}{c}\text { Asymp. } \\
\text { Sig. }\end{array} \\
, 001\end{array}$} \\
\hline \multirow{2}{*}{ K1 } & \multirow{2}{*}{$\begin{array}{l}\text { Restorasyon çalışmaları Kayseri ilinin tarihi geçmişini } \\
\text { yok etmiştir. }\end{array}$} & & & & & & \\
\hline & & Erkek & 28 & 49 & 108 & & \\
\hline \multirow{2}{*}{$\mathrm{K} 2$} & \multirow{2}{*}{$\begin{array}{l}\text { Restorasyon çalışmaları ile Kayseri tarihi koruma } \\
\text { çalışmaları yeterlidir. }\end{array}$} & Kadın & 134 & 91 & 40 & \multirow{2}{*}{9,004 (a) } & \multirow{2}{*}{, 011} \\
\hline & & Erkek & 119 & 42 & 24 & & \\
\hline \multirow{2}{*}{ K3 } & \multirow{2}{*}{$\begin{array}{l}\text { Restorasyon çalışmaları kentin oluştuğu dönemin } \\
\text { özelliklerini yansıtmaktadır. }\end{array}$} & Kadın & 155 & 40 & 70 & \multirow{2}{*}{$2,610(a)$} & \multirow{2}{*}{,271 } \\
\hline & & Erkek & 120 & 28 & 37 & & \\
\hline \multirow{2}{*}{ K4 } & \multirow{2}{*}{$\begin{array}{l}\text { Restorasyon çalışmaları sonrasında kale içerisindeki } \\
\text { rekreasyon ve sosyal kullanım alanları yeterli olmuştur. }\end{array}$} & Kadın & 121 & 78 & 66 & \multirow{2}{*}{3,486 (a) } & \multirow{2}{*}{, 175 } \\
\hline & & Erkek & 101 & 46 & 38 & & \\
\hline \multirow{2}{*}{ K5 } & \multirow{2}{*}{$\begin{array}{l}\text { Restorasyon çalışmaları Kale'nin çevresindeki kullanım } \\
\text { alanları ile bağlantılıdır. }\end{array}$} & Kadın & 100 & 96 & 69 & \multirow{2}{*}{3,763 (a) } & \multirow{2}{*}{,152 } \\
\hline & & Erkek & 86 & 54 & 45 & & \\
\hline \multirow{2}{*}{ K6 } & \multirow{2}{*}{$\begin{array}{l}\text { Restorasyon çalışmaları sonrasında yapılan kullanım } \\
\text { alanları yeterlidir. }\end{array}$} & Kadın & 106 & 96 & 63 & \multirow{2}{*}{ 6,792 (a) } & \multirow{2}{*}{,003 } \\
\hline & & Erkek & 79 & 52 & 54 & & \\
\hline \multirow{2}{*}{ K7 } & \multirow{2}{*}{$\begin{array}{l}\text { Restorasyon sonrasında çevredeki güvenlik çalışmaları } \\
\text { yeterli düzeyde olmaktadır. }\end{array}$} & Kadın & 75 & 127 & 63 & \multirow{2}{*}{$1,672(a)$} & \multirow{2}{*}{,433 } \\
\hline & & Erkek & 55 & 78 & 52 & & \\
\hline \multirow{2}{*}{ K8 } & \multirow{2}{*}{$\begin{array}{l}\text { Restorasyon çalışmalarından yerli ve yabancı turistlerin } \\
\text { haberi vardır. }\end{array}$} & Kadın & 42 & 137 & 86 & \multirow{2}{*}{8,548 (a) } & 010 \\
\hline & & Erkek & 50 & 86 & 49 & & , 010 \\
\hline & $2: \mathrm{Ka}$ & & & & & & \\
\hline & & & & & & & \\
\hline
\end{tabular}

Kayseri Kalesi restorasyon çalışmaları memnuniyeti katılımcıların yaşları açısından değerlendirildiğinde, K1, K2, K3, K4, K6, K7 ve K8 kriterleri ile 26-35 yaş aralığından olan katılımcıların görüşlerinin istatistiki açıdan anlamlı olduğu görülmektedir $(\mathrm{p}<0,005)$. Restorasyon çalışmalarından genel olarak memnuniyetsizlik durumu tüm yaş gruplarında mevcuttur. Fakat bu oranın 26-35 yaş aralığında olan katılımcılarda daha fazla olduğu tespit edilmiştir (Tablo 5).

Tablo 5. Katılımcıların yaşları ile memnuniyet düzeylerinin karşılaştırılması

\begin{tabular}{|c|c|c|c|c|c|c|c|}
\hline & Kriterler & Yaş & 1 & 2 & 3 & $\begin{array}{c}\text { Chi- } \\
\text { Square }\end{array}$ & $\begin{array}{l}\text { Asymp. } \\
\text { Sig. }\end{array}$ \\
\hline \multirow{5}{*}{ K1 } & \multirow{5}{*}{$\begin{array}{l}\text { Restorasyon çalışmaları Kayseri ilinin } \\
\text { tarihi geçmişini yok etmiştir. }\end{array}$} & $18-25$ & 39 & 47 & 112 & \multirow{5}{*}{16,351 (a) } & \multirow{5}{*}{,030 } \\
\hline & & $26-35$ & 56 & 27 & 126 & & \\
\hline & & $36-45$ & 7 & 2 & 13 & & \\
\hline & & $46-55$ & 3 & 5 & 11 & & \\
\hline & & $56+$ & 0 & 0 & 2 & & \\
\hline \multirow{2}{*}{$\mathrm{K} 2$} & \multirow{2}{*}{$\begin{array}{l}\text { Restorasyon çalışmaları ile Kayseri } \\
\text { tarihi koruma çalışmaları yeterlidir. }\end{array}$} & $18-25$ & 127 & 33 & 38 & \multirow{2}{*}{21,241 (a) } & \multirow{2}{*}{,000 } \\
\hline & & $26-35$ & 137 & 50 & 22 & & \\
\hline
\end{tabular}




\begin{tabular}{|c|c|c|c|c|c|c|c|}
\hline & & $36-45$ & 13 & 5 & 4 & & \\
\hline & & $46-55$ & 14 & 5 & 0 & & \\
\hline & & $56+$ & 2 & 0 & 0 & & \\
\hline \multirow{5}{*}{ K3 } & \multirow{5}{*}{$\begin{array}{l}\text { Restorasyon çalışmaları kentin oluştuğu } \\
\text { dönemin özelliklerini yansıtmaktadır. }\end{array}$} & $18-25$ & 130 & 13 & 55 & \multirow{5}{*}{26,756 (a) } & \multirow{5}{*}{, 001} \\
\hline & & $26-35$ & 144 & 23 & 42 & & \\
\hline & & $36-45$ & 10 & 5 & 7 & & \\
\hline & & $46-55$ & 14 & 2 & 3 & & \\
\hline & & $56+$ & 2 & 0 & 0 & & \\
\hline \multirow{5}{*}{$\mathrm{K} 4$} & \multirow{5}{*}{$\begin{array}{l}\text { Restorasyon çalışmaları sonrasında kale } \\
\text { içerisindeki rekreasyon ve sosyal } \\
\text { kullanım alanları yeterli olmuştur. }\end{array}$} & $18-25$ & 100 & 50 & 47 & \multirow{5}{*}{16,761 (a) } & \multirow{5}{*}{$\mathbf{0 , 3 3}$} \\
\hline & & $26-35$ & 129 & 33 & 47 & & \\
\hline & & $36-45$ & 8 & 9 & 5 & & \\
\hline & & $46-55$ & 15 & 2 & 2 & & \\
\hline & & $56+$ & 0 & 0 & 2 & & \\
\hline \multirow{5}{*}{ K5 } & \multirow{5}{*}{$\begin{array}{l}\text { Restorasyon çalışmaları Kale'nin } \\
\text { çevresindeki kullanım alanları ile } \\
\text { bağlantılıdır. }\end{array}$} & $18-25$ & 84 & 58 & 56 & \multirow{5}{*}{13,569 (a) } & \multirow{5}{*}{,094 } \\
\hline & & $26-35$ & 82 & 75 & 52 & & \\
\hline & & $36-45$ & 11 & 9 & 2 & & \\
\hline & & $46-55$ & 9 & 8 & 2 & & \\
\hline & & $56+$ & 0 & 0 & 2 & & \\
\hline \multirow{5}{*}{ K6 } & \multirow{5}{*}{$\begin{array}{l}\text { Restorasyon çalışmaları sonrasında } \\
\text { yapılan kullanım alanları yeterlidir. }\end{array}$} & $18-25$ & 49 & 74 & 75 & \multirow{5}{*}{22,456 (a) } & \multirow{5}{*}{, 000} \\
\hline & & $26-35$ & 110 & 73 & 26 & & \\
\hline & & $36-45$ & 2 & 11 & 9 & & \\
\hline & & $46-55$ & 6 & 8 & 5 & & \\
\hline & & $56+$ & 2 & 0 & 0 & & \\
\hline \multirow{5}{*}{ K7 } & \multirow{5}{*}{$\begin{array}{l}\text { Restorasyon sonrasında çevredeki } \\
\text { güvenlik çalışmaları yeterli düzeyde } \\
\text { olmaktadır. }\end{array}$} & $18-25$ & 78 & 53 & 67 & \multirow{5}{*}{24,439 (a) } & \multirow{5}{*}{,002 } \\
\hline & & $26-35$ & 89 & 79 & 41 & & \\
\hline & & $36-45$ & 5 & 10 & 7 & & \\
\hline & & $46-55$ & 11 & 6 & 2 & & \\
\hline & & $56+$ & 2 & 0 & 0 & & \\
\hline \multirow{5}{*}{ K8 } & \multirow{5}{*}{$\begin{array}{l}\text { Restorasyon çalışmalarından yerli ve } \\
\text { yabancı turistlerin haberi vardır. }\end{array}$} & $18-25$ & 51 & 87 & 60 & & \multirow{5}{*}{,002 } \\
\hline & & $26-35$ & 38 & 115 & 56 & \multirow{4}{*}{20,637 (a) } & \\
\hline & & $36-45$ & 3 & 8 & 11 & & \\
\hline & & $46-55$ & 0 & 13 & 6 & & \\
\hline & & $56+$ & 0 & 0 & 2 & & \\
\hline
\end{tabular}

Kayseri Kalesi restorasyon çalışması memnuniyetinin katılımcıların eğitim düzeyleri açısından değerlendirilmesinde; katılımcıların eğitim düzeyleri ve $\mathrm{K} 1, \mathrm{~K} 2, \mathrm{~K} 3, \mathrm{~K} 7$ ve K8 kriterleri arasında istatistiki açıdan anlamlı bir ilişki olduğu görülmektedir $(\mathrm{p}<0,05)$. Restorasyon çalışması memnuniyet düzeyinin üniversite düzeyinde olan katılımcılarda daha az olduğu görülmektedir (Tablo 6).

Tablo 6. Katılımcıların eğitim düzeyleri ile memnuniyetlerinin karşılaştırılması

\begin{tabular}{|c|c|c|c|c|c|c|c|}
\hline & Kriterler & Eğitim & 1 & 2 & 3 & Chi-Square & $\begin{array}{l}\text { Asymp. } \\
\text { Sig. }\end{array}$ \\
\hline \multirow{5}{*}{ K1 } & \multirow{5}{*}{$\begin{array}{l}\text { Restorasyon çalışmaları Kayseri ilinin } \\
\text { tarihi geçmişini yok etmiştir. }\end{array}$} & İlkokul & 7 & 0 & 5 & \multirow{5}{*}{21,314 (a) } & \multirow{5}{*}{,003 } \\
\hline & & Ortaokul & 0 & 2 & 0 & & \\
\hline & & Lise & 46 & 67 & 98 & & \\
\hline & & Üniversite & 52 & 52 & 119 & & \\
\hline & & Lisansüstü & 0 & 0 & 2 & & \\
\hline \multirow{5}{*}{$\mathrm{K} 2$} & \multirow{5}{*}{$\begin{array}{l}\text { Restorasyon çalışmaları ile Kayseri tarihi } \\
\text { koruma çalışmaları yeterlidir. }\end{array}$} & İlkokul & 5 & 3 & 4 & \multirow{5}{*}{17,174 (a) } & \multirow{5}{*}{, 002} \\
\hline & & Ortaokul & 0 & 2 & 0 & & \\
\hline & & Lise & 116 & 73 & 22 & & \\
\hline & & Üniversite & 130 & 55 & 38 & & \\
\hline & & Lisansüstü & 2 & 0 & 0 & & \\
\hline \multirow{4}{*}{$\mathrm{K} 3$} & \multirow{4}{*}{$\begin{array}{l}\text { Restorasyon çalışmaları kentin oluştuğu } \\
\text { dönemin özelliklerini yansıtmaktadır. }\end{array}$} & İlkokul & 2 & 3 & 7 & \multirow{4}{*}{26,472 (a) } & \multirow{4}{*}{,001 } \\
\hline & & Ortaokul & 0 & 2 & 0 & & \\
\hline & & Lise & 128 & 37 & 46 & & \\
\hline & & Üniversite & 143 & 26 & 54 & & \\
\hline
\end{tabular}




\begin{tabular}{|c|c|c|c|c|c|c|c|}
\hline & & Lisansüstü & 2 & 0 & 0 & & \\
\hline \multirow{5}{*}{ K4 } & \multirow{5}{*}{$\begin{array}{l}\text { Restorasyon çalışmaları sonrasında kale } \\
\text { içerisindeki rekreasyon ve sosyal } \\
\text { kullanım alanları yeterli olmuştur. }\end{array}$} & İlkokul & 3 & 7 & 2 & \multirow{5}{*}{17,993 (a) } & \multirow{5}{*}{,273 } \\
\hline & & Ortaokul & 0 & 2 & 0 & & \\
\hline & & Lise & 101 & 59 & 51 & & \\
\hline & & Üniversite & 118 & 54 & 51 & & \\
\hline & & Lisansüstü & 0 & 2 & 0 & & \\
\hline \multirow{5}{*}{ K5 } & \multirow{5}{*}{$\begin{array}{l}\text { Restorasyon çalışmaları Kale'nin } \\
\text { çevresindeki kullanım alanları ile } \\
\text { bağlantılıdır. }\end{array}$} & İlkokul & 3 & 7 & 2 & \multirow{5}{*}{12,146 (a) } & \multirow{5}{*}{,145 } \\
\hline & & Ortaokul & 0 & 2 & 0 & & \\
\hline & & Lise & 92 & 67 & 52 & & \\
\hline & & Üniversite & 91 & 72 & 60 & & \\
\hline & & Lisansüstü & 0 & 2 & 0 & & \\
\hline \multirow{5}{*}{ K6 } & \multirow{5}{*}{$\begin{array}{l}\text { Restorasyon çalışmaları sonrasında } \\
\text { yapılan kullanım alanları yeterlidir. }\end{array}$} & İlkokul & 5 & 5 & 2 & \multirow{5}{*}{11,296 (a) } & \multirow{5}{*}{, 185 } \\
\hline & & Ortaokul & 0 & 2 & 0 & & \\
\hline & & Lise & 82 & 80 & 49 & & \\
\hline & & Üniversite & 88 & 69 & 66 & & \\
\hline & & Lisansüstü & 0 & 2 & 0 & & \\
\hline \multirow{5}{*}{ K7 } & \multirow{5}{*}{$\begin{array}{l}\text { Restorasyon sonrasında çevredeki } \\
\text { güvenlik çalışmaları yeterli düzeyde } \\
\text { olmaktadır. }\end{array}$} & İlkokul & 2 & 6 & 4 & \multirow{5}{*}{17,972 (a) } & \multirow{5}{*}{, 002} \\
\hline & & Ortaokul & 0 & 2 & 0 & & \\
\hline & & Lise & 73 & 99 & 39 & & \\
\hline & & Üniversite & 55 & 96 & 72 & & \\
\hline & & Lisansüstü & 0 & 2 & 0 & & \\
\hline \multirow{5}{*}{ K8 } & \multirow{5}{*}{$\begin{array}{l}\text { Restorasyon çalışmalarından yerli ve } \\
\text { yabancı turistlerin haberi vardır. }\end{array}$} & İlkokul & 0 & 4 & 8 & \multirow{5}{*}{19,507 (a) } & \multirow{5}{*}{, 000} \\
\hline & & Ortaokul & 0 & 2 & 0 & & \\
\hline & & Lise & 34 & 109 & 68 & & \\
\hline & & Üniversite & 58 & 106 & 59 & & \\
\hline & & Lisansüstü & 0 & 2 & 0 & & \\
\hline \multicolumn{8}{|c|}{ 1: Katılmiyorum, 2: Kararsizım, 3: Kattllyorum } \\
\hline & & & & & & & \\
\hline
\end{tabular}

Son olarak ise, Kayseri Kalesi restorasyon çalışmaları memnuniyeti katılımcıların meslekleri açısından değerlendirilmiştir. Değerlendirme sonucunda katılımcıların meslekleri ve K1, K2, K4, K5 ve K8 kriterleri arasında istatistiki açıdan anlamlı bir ilişki olduğu tespit edilmiştir. ( $\mathrm{p}<0,05)$. Restorasyon çalışması memnuniyet düzeyinin kamu sektöründe çalışmakta olan katılımcılarda daha az olduğu görülmektedir (Tablo 7).

Tablo 7. Katılımcıların meslekleri ile memnuniyet düzeylerinin karşılaştırılması

\begin{tabular}{|c|c|c|c|c|c|c|c|}
\hline & Kriterler & Meslek & 1 & 2 & 3 & $\begin{array}{c}\text { Chi- } \\
\text { Square }\end{array}$ & $\begin{array}{c}\text { Asymp. } \\
\text { Sig. }\end{array}$ \\
\hline \multirow{6}{*}{ K1 } & \multirow{6}{*}{$\begin{array}{l}\text { Restorasyon çalışmaları Kayseri ilinin } \\
\text { tarihi geçmişini yok etmiştir. }\end{array}$} & Kamu sektörü & 62 & 72 & 94 & \multirow{6}{*}{29,696 (a) } & \multirow{6}{*}{,001 } \\
\hline & & Özel sektör & 16 & 30 & 68 & & \\
\hline & & Öğrenci & 17 & 12 & 37 & & \\
\hline & & Ev hanımı & 4 & 2 & 9 & & \\
\hline & & Emekli & 0 & 5 & 11 & & \\
\hline & & Serbest meslek & 6 & 0 & 5 & & \\
\hline \multirow{6}{*}{ K2 } & \multirow{6}{*}{$\begin{array}{l}\text { Restorasyon çalışmaları ile Kayseri tarihi } \\
\text { koruma çalışmaları yeterlidir. }\end{array}$} & Kamu sektörü & 121 & 69 & 38 & \multirow{6}{*}{24,824 (a) } & \multirow{6}{*}{, 000} \\
\hline & & Özel sektör & 63 & 31 & 20 & & \\
\hline & & Öğrenci & 38 & 26 & 2 & & \\
\hline & & Ev hanımı & 9 & 2 & 4 & & \\
\hline & & Emekli & 11 & 5 & 0 & & \\
\hline & & Serbest meslek & 11 & 0 & 0 & & \\
\hline \multirow{6}{*}{ K3 } & \multirow{6}{*}{$\begin{array}{l}\text { Restorasyon çalışmaları kentin oluştuğu } \\
\text { dönemin özelliklerini yansıtmaktadır. }\end{array}$} & Kamu sektörü & 131 & 43 & 54 & \multirow{6}{*}{17,082 (a) } & \multirow{6}{*}{, 073} \\
\hline & & Özel sektör & 71 & 14 & 29 & & \\
\hline & & Öğrenci & 45 & 7 & 14 & & \\
\hline & & Ev hanımı & 6 & 2 & 7 & & \\
\hline & & Emekli & 14 & 2 & 0 & & \\
\hline & & Serbest meslek & 8 & 0 & 3 & & \\
\hline \multirow{3}{*}{ K4 } & \multirow{3}{*}{$\begin{array}{l}\text { Restorasyon çalışmaları sonrasında kale } \\
\text { içerisindeki rekreasyon ve sosyal } \\
\text { kullanım alanları yeterli olmuştur. }\end{array}$} & Kamu sektörü & 110 & 70 & 48 & \multirow{3}{*}{27,522 (a) } & \multirow{3}{*}{,002 } \\
\hline & & Özel sektör & 54 & 26 & 34 & & \\
\hline & & Öğrenci & 35 & 18 & 13 & & \\
\hline
\end{tabular}




\begin{tabular}{|c|c|c|c|c|c|c|c|}
\hline & & Ev hanımı & 3 & 10 & 2 & & \\
\hline & & Emekli & 12 & 0 & 4 & & \\
\hline & & Serbest meslek & 8 & 0 & 3 & & \\
\hline \multirow{6}{*}{ K5 } & \multirow{6}{*}{$\begin{array}{l}\text { Restorasyon çalışmaları Kale'nin } \\
\text { çevresindeki kullanım alanları ile } \\
\text { bağlantılıdır. }\end{array}$} & Kamu sektörü & 98 & 76 & 54 & \multirow{6}{*}{24,123 (a) } & \multirow{6}{*}{, 002} \\
\hline & & Özel sektör & 47 & 28 & 39 & & \\
\hline & & Öğrenci & 24 & 32 & 10 & & \\
\hline & & Ev hanımı & 3 & 8 & 4 & & \\
\hline & & Emekli & 6 & 6 & 4 & & \\
\hline & & Serbest meslek & 8 & 0 & 3 & & \\
\hline \multirow{6}{*}{ K6 } & \multirow{6}{*}{$\begin{array}{l}\text { Restorasyon çalışmaları sonrasında } \\
\text { yapılan kullanım alanları yeterlidir. }\end{array}$} & Kamu sektörü & 81 & 93 & 54 & \multirow{6}{*}{13,179 (a) } & \multirow{6}{*}{,214 } \\
\hline & & Özel sektör & 53 & 31 & 30 & & \\
\hline & & Öğrenci & 23 & 21 & 22 & & \\
\hline & & Ev hanımı & 7 & 4 & 4 & & \\
\hline & & Emekli & 8 & 6 & 2 & & \\
\hline & & Serbest meslek & 3 & 3 & 5 & & \\
\hline \multirow{6}{*}{ K7 } & \multirow{6}{*}{$\begin{array}{l}\text { Restorasyon sonrasında çevredeki } \\
\text { güvenlik çalışmaları yeterli düzeyde } \\
\text { olmaktadır. }\end{array}$} & Kamu sektörü & 108 & 69 & 51 & \multirow{6}{*}{12,896 (a) } & \multirow{6}{*}{,230 } \\
\hline & & Özel sektör & 45 & 32 & 37 & & \\
\hline & & Öğrenci & 34 & 21 & 11 & & \\
\hline & & Ev hanımı & 7 & 2 & 6 & & \\
\hline & & Emekli & 8 & 3 & 5 & & \\
\hline & & Serbest meslek & 3 & 3 & 5 & & \\
\hline \multirow{6}{*}{ K8 } & \multirow{6}{*}{$\begin{array}{l}\text { Restorasyon çalışmalarından yerli ve } \\
\text { yabancı turistlerin haberi vardır. }\end{array}$} & Kamu sektörü & 50 & 130 & 48 & \multirow{6}{*}{32,394 (a) } & \multirow{6}{*}{,000 } \\
\hline & & Özel sektör & 22 & 42 & 5 & & \\
\hline & & Öğrenci & 17 & 25 & 24 & & \\
\hline & & Ev hanımı & 0 & 10 & 5 & & \\
\hline & & Emekli & 0 & 11 & 5 & & \\
\hline & & Serbest meslek & 3 & 5 & 3 & & \\
\hline
\end{tabular}

\section{Tartışma ve Sonuç}

Tarihi ve kültürel çevreler kentlerin sosyal ve fiziksel yapıları içerisinde "düğüm noktaları" niteliğindedir. Kentlerin inşa edildikleri dönemin birikimlerini, deneyimlerini ve o dönemlere ait özellikleri aktarmaları açısından kentlerin okunabilirliğine katkı sağlamaktadırlar. Bu bağlamda tarihi çevreler kentsel alanlar içerisinde öncelikli olarak korunması gereken bölgelerdir. Kentlerin kimliklerini korumaları sadece yapı bazında bir koruma anlayışı ile mümkün olmayıp bütüncül bir koruma anlayışının benimsenmesi gerekmektedir. Bütüncül bir koruma anlayışı ise, koruma gereksinimleri ile planlama hedeflerini birlikte değerlendirmeyi gerektirir. Bu bağlamda koruma politikalarının sadece fiziksel boyutta değil aynı zamanda sosyal boyut açısından da ele alınması gerekmektedir. Bu durum kent kimliklerini olumlu yönde etkileyeceği gibi yöre halkının da yaşadığı çevreye farklı bir gözle bakmasını sağlayarak, kentlerin gelişimlerine olumlu yönde katkı sağlayacaktır.

Araştırma kapsamında koruma süreci sosyal açıdan ele alınmış olup, yerel halkın koruma süreçlerindeki rolü incelenmiştir. Bu çerçevede, Kayseri Kalesi restorasyon çalışması ele alınmış, bu bölgede yaşayan insanların katılımıyla anket tekniği ile değerlendirilmiştir. Elde edilen bulgular kapsamlı olarak değerlendirildiğinde, Kayseri Kalesi ve bulunduğu çevreyi korumak amacıyla yapılmış olan restorasyon çalışmalarından genel anlamda yerel halkın memnuniyet düzeyi oldukça düşüktür. Restorasyon çalışmalarının alanın özgün dokusuna uygun olmaması, çevresi ile bir bütünlük oluşturmaması yerel halk tarafindan memnuniyetsizlikle karşılanmıştır. Yapılan bu restorasyon çalışmalarının planlama aşamasında kullanıcı istek ve taleplerinin iyi belirlenmesi gerekmektedir.

Restorasyon çalışmalarından yerli ve yabancı turistlerin haberdar olup olmadığının bilinmemesi ulaşılan önemli bir sonuç olmuştur. Turistlerin tarihi ve kültürel özelliklere sahip çevreleri ziyaret etmesi aynı zamanda yöre halkının da ekonomik açıdan kalkınmasına katkı sağlamaktadır. Böylelikle kentlerde tanınma oranlarının artmasıyla tarihi, sosyal ve ekonomik açıdan gelişmektedir. Bu kapsamda turizm potansiyelinin temelini oluşturan doğal, tarihi ve kültürel çevrelerin korunması amacıyla yapılacak çalışmalarda yerel halkın olumlu yönde oluşacak tutumu büyük önem taşımaktadır. Memnuniyet düzeylerinin katılımcıların demografik özelliklere göre değişkenlik gösterdiği tespit edilmiştir. Bu demografik özelliklerden ilki cinsiyettir. Restorasyon çalışmalarından; kent tarihinin zarar görmesi, kentin oluştuğu dönemin özelliklerini yansıtmadığı, kale içerisinde rekreasyon ve sosyal kullanım alanlarının yetersiz olması, güvenliğin yetersiz olması durumları açısından 
bakıldığında genel anlamda memnuniyet düzeyinin oldukça düşük olduğu tespit edilmiştir. Bu memnuniyet düzeyi kadın katılımcılarda erkeklere oranla daha düşük olmuştur. Kadınların tarihi kültürel çevrelerde yapılan koruma çalışmalarının, bölgeye sosyal, çevresel ve ekonomik etkilerine yönelik düşüncelerinde de farklılıklar olması memnuniyet düzeylerinin düşük olmasına neden olmuştur. Bu bağlamda, kadınların restorasyon çalışmalarına yönelik düşüncelerinin erkeklere oranla daha olumsuz olduğunu söylemek mümkündür. Değişkenlik gösteren diğer demografik özellik katılımcıların yaşları olmuştur. 18-25 ve 26-34 yaş gruplarında olan katılımcılarda memnuniyet düzeyi düşüktür. Tarihi çevrede yaşayan üniversite düzeyinde eğitim seviyesine sahip katılımcılarında, memnun olmadıkları sonucuna ulaşılmıştır. Son olarak memnuniyeti etkileyen bir diğer demografik özellik ise yerel halkın meslekleri olmuştur. Kamu sektöründe çalışan katılımcıların memnuniyet düzeyleri daha düşük olmuştur.

Literatürde yerel halkın turizm algısına yönelik çok sayıda çalışma yapılmıştır. Yapılan bu çalışmalarda turizmin genel anlamda yerel halkın yaşamını büyük ölçüde etkilediği belirlenmiştir. Turizmin ilgili destinasyona avantajlar sağlamasından dolayı yerel halkın turizm algısının olumlu olduğu sonucuna ulaşılmıştır (Andereck vd.,2005; Zaei ve Zaei, 2013; Şanlığlu ve Erdem, 2017). Güzel vd. (2019) yapmış oldukları çalışmada kültürel açıdan önemli olan alanların/binaların restore edilerek turizme kazandırılması konusunda katılımcıların olumlu izlenimleri olduğu sonucuna ulaşmışlardır. Kültürel yapılar turizm için fazladan bir değer oluşturmaktadır (Reisinger ve Steiner, 2006). Planlama ve turizm alanında kentleri geliştirmek için mimari ve turizm ilişkisi önemlidir. Restorasyon çalışmalarının turizm sektörünü sosyal, kültürel ve ekonomik açıdan önemli ölçüde etkilemektedir. Yerel halkın refah düzeyine, turizm bilincine, alanın tanıtımına büyük oranda katkıları olmasının yanı sıra yanlış uygulamalar, mimari dokunun bozulması gibi hataların yapılması ise hem bölgeyi hem de yerel halkı olumsuz yönde etkilemektedir (Avc1, 2007; Sak ve Karymshakov, 2012; Güzel vd., 2019). Çalışmada tarihi ve kültürel çevreyi korumak amacıyla yapılan Kayseri Kalesi restorasyon çalışmalarına olumsuz olarak yaklaşıldığı, olumlu düşünceye sahip katılımcıların sayısı oldukça az sayıda olduğu görülmektedir. Bu bağlamda restorasyon çalışmalarının turizme ve yerel halka olumlu yönde katkı sağlamasının gerekliliği ortaya konmuştur.

Tarihi ve kültürel açıdan önemli bölgelerin korunması kent turizmine büyük oranda katkı sağladığından, yapılması gereken bir bölgede turizmin planlı gelişiminin sağlanmasıdır. Bu çerçevede, olumsuz durumların ortadan kalkması veya azalması için gerekli tedbirler alınarak koruma çalışmaları sonucunda ortaya çıkan problemler en aza indirilmiş olacaktır. Tarihi çevre koruma çalışmalarında bölgede yaşayan halkın da katılımı kentin gelişimine katkı sağlanması açısından önemlidir. Çalışmada, önemli bir tarihi geçmişe sahip olan Kayseri ilinde koruma çalışmalarında halkında görüşlerinin dikkate alınmasına dikkat çekilerek kentin kültür turizmi bağlamında planlı bir şekilde gelişmesine yardımcı olması hedeflenmiştir.

Günümüz değişen turizm anlayışıyla beraber önemli tarihi eserlerin, anıtların olduğu çevreler oldukça önem kazanmaya başlamıştır. Bu bağlamda, tarihi-kültürel birikimlerin bu anlamda korunması ve özellikle doğru bir şekilde yansıtılması aynı zamanda kentlerin kalkınmasının da önemli bir parçası haline gelmektedir. Tarihi ve kültürel çevrelerin korunmasında yaşanan sürece ilişkin ve süreçte ortaya çıkan problemlerin nicelik ve niteliğinde yerel yönetimlerin rolünü sorgulayan çok sayıda çalışma bulunmaktadır. Fakat söz konusu süreçte yerel halkın rolünü araştıran çalışmalar sınırlı sayıdadır. Araştırma bu bağlamda özgün bir niteliğe sahiptir. 


\section{KAYNAKLAR}

Ahunbay, Z. 2004. Tarihî Çevre Koruma ve Restorasyon, Yapı. Yayın:28, İstanbul

Andereck, K. L., K. M. Valentine, R. C. Knopf and C. A. Vogt. (2005). "Residents' Perceptions Of Community Tourism Impacts", Annals Of Tourism Research, 32(4), 1056-1076.

Arabacıoğlu, F.P., Aydemir, I. 2007. Tarihi Çevrelerde Yeniden Değerlendirme Kavramı. Ylldız Teknik Üniversitesi Mimarlık Fakültesi Dergisi, 2 (4), 204-212.

Aslan, F., Uzun, A. (2020). Tarihi Çevrenin Korunmasına Yönelik Yerel Halk Algısının Belirlenmesi: Metropolis Antik Kenti Örneği (Torbalı). Uluslararası Sosyal Araştırmalar Dergisi, 13(69).

Avcı. N. (2007). Turizmde Taşıma Kapasitesinin Önemi. Ege Akademik Bakış Dergisi, 7(2),485-501.

Avcıkurt, C., (2003). Turizm Sosyolojisi; Turist-Yerel Halk Etkileşimi. Detay Yayınlarl, Ankara.

Çam, O., Çılgınoğlu, H. (2020). Kastamonu İli Turizm Potansiyeli ve İnanç Turizminin Şehirdeki Yeri ve Önemi. Uluslararası Türk Dünyası Turizm Araştırmaları Dergisi, 5(1), s.46-90.

Çayırdağ, M., (2001). Kayseri tarihi araştırmaları, Kayseri Büyükşehir Belediyesi Yayını, Kayseri.

Çırak, A. A. (2010). Korumanın Toplumsal ve Kültürel Boyutu Neden Önemli? Biz Nasıl Bakıyoruz? Planlama, (1), s. 29-37.

Dönmez, Y. ve Türkmen, F. (2015). Turistlerin Satın Alma Kararında Peyzaj Düzenlemelerinin Rolü: Belek Örneği. Turizm Akademik Dergisi, 2(2).

Mansuroğlu, S., (2006). Turizm Gelişmelerine Yerel Halkın Yaklaşımlarının Belirlenmesi: Akseki/Antalya Örneği. Akdeniz Üniv. Ziraat Fakültesi Dergisi, Sayl:19.

Nijkamp, P., and Riganti, P. (2009). Valuing urban cultural heritage. In L. Fusco Girard \& P. Nijkamp (Eds.), Cultural tourism and sustainable local development. Farnham: Ashgate Publishing Limited.

Onur Güzel, M., Barakazı, M., \& Çakır, P. G. (2019). Şehir turizmine hizmet verebilecek tarihi yapılarda restorasyon (yenileme): Şanlıurfa konukevleri örneği. Journal of Socialand Humanities Sciences Research, 6(44),3666-3675.

Ozturk, S., Isinkaralar, Ö, Yilmaz, D. and Cicek, E. (2021). Tourists' Perspective Of Cultural Heritage Areas: Importance-Performance Analysis Of Safranbolu, Research \& Reviews In Architecture, Planning And Design, Gece Akademi, Chapter 7, pp.133-156.

Ozturk, S., Isinkaralar. O. ve Ayan, E. (2018). Visibility Analysis in Historical Environments: The case of Kastamonu Castle and its Surrounding. Journal of Current Researches on Social Sciences, 8 (4), 405 412.

Önaç, Kalaycı, A., Balık, G., Aktaş, E. Ve Birişçi, T. (2018). Kuşadası Kent Markalaşması Sürecinde Kentsel Peyzaj Değerlerinin Rolü. Kuşadası Peyzaj Değerleri, Peyzaj Mimarlığı Odası, s.194-204.

Öztürk S., Işınkaralar, Ö., Yılmaz, D. (2019). Cittaslow Hareketi ve Toplumsal Farkındalık: Gerze Sinop Örneği, Academic Sciences on Social and Education Sciences, Kitap Bölümü, Gece Akademi, Chapter 1, s.1-14.

Perucca, G. (2018). Residents' Satisfaction with Cultural City Life: Evidence from EU Cities. Applied Research Quality Life, 14, pp. 461-478.

Phillips, A. (2002). Management Guidelines for IUCN Category V Protected Areas: Protected Landscapes/Seascapes. IUCN (E.T.https://www.iucn.org/content/management-guidelines-iucncategory-v-protected-areas-protected-landscapesseascapes-0)

Reisinger, Y., Steiner, C. (2006). Reconceptualisinginterpretation: The role of tourguides in authentictourism. CurrentIssues in Tourism, 9(6), 481-498.

Sak, N., Karymshakov, K. (2012). Relationship between tourism and economic growth: A panel Grangerca usality approach. Asian economic and financial review, 2(5), 591-602.

Subaşı, M. İ. (1998). Dünden Bugüne Kayseri, 4. Baskı, Geçit, Kayseri. 
Şanlığlu, Ö., Erdem, A. (2017). Kayseri Örneğinde Yerel Halkın Turizm Faaliyetlerini Nasıl Algıladığının Tespitine Yönelik Bir Araştırma. Pamukkale Üniversitesi Sosyal Bilimler Enstitüsü Dergisi, (27), 277298.

Tırnakçı, A., Aklıbaşında, M. (2018). Tarihi Çevrelerde Kentsel Peyzaj Tasarımın Kayseri Mimar Sinan Parkı Örneğinde İncelenmesi. Erciyes Üniversitesi Fen Bilimleri Enstitüsü Dergisi 34(3).

Zaei, M. E., Zaei, M. E. (2013). “The Impacts Of Tourism Industry On Host Community”. European Journal Of Tourism Hospitality And Research, 1(2), 12-21. 